\title{
Contents/Contenido
}

Acknowledgments/Agradecimientos ix

Abbreviations/Abreviaturas $\mathrm{xi}$

\section{Carlos Montemayor}

Past and Present Writing in Indigenous Languages $\quad 1$

Pasado y presente de la escritura en lenguas indígenas 8

\section{Donald Frischmann}

The Indigenous Word in Mesoamerica: Orality, Writing, and Contemporary Prose 16

La Palabra indígena mesoamericana: Oralidad y escritura y la prosa contemporánea 30

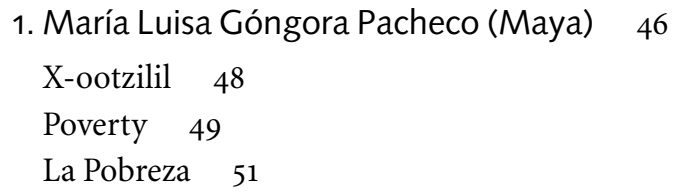

2. Jorge Echeverría Lope (Maya) 54

X-La'Boon-Suumij 56

Ancient Rope Marks 61

Vieja huella de soga $\quad 66$

3. Miguel Ángel May May (Maya) 72

Jump'éel tzikbaal yo'olal Yum Tzilo'ob 74

A Story about Yum Tziles $\quad 76$

Una narración sobre Yum Tziles $\quad 78$

4. Santiago Domínguez Aké (Maya) 82

U pa'ak'al Ixi'im 84

The Sowing of Corn 86

La siembra del Maíz $\quad 88$
5. Isaías Hernández Isidro (Tabasco Chontal) 90

U ch'ujlom k'ajalin ta Zutz’baläm 92

The Secret of the Zutz'baläm 94

El secreto del Zutz’baläm 96

6. Enrique Pérez López (Tzotzil) 100

K'ox xchi'uk yajval vo' 102

K'ox and the Lord of the Water 106

K’ox y el Dueño del agua 110

\section{Jacinto Arias Pérez (Tzotzil) 114}

Xch'unel sk'op kajvaltik ta ch'ul na xchi'uk li jtsotsil jtseltaletike 116

Catholic Beliefs among the Tzotziles and Tzeltales $\quad 121$

Las creencias católicas entre los tzotziles y los tzeltales 125

8. Diego Méndez Guzmán (Tzeltal) 130

Lok' ta beel te Kajkanantike 132

Saint Ildefonso's Pilgrimage 133

Peregrinar de San Ildefonso 135

9. Domingo Gómez Gutiérrez (Tzeltal) 138

Bats'il Ajaw Jwan Lopes, Kanan Chij (Jman Enantes, Swijlibja, Chilón) 140

Juan López, the Tzeltal Ajaw and Shepherd (Manuel Hernández, Swijlibjá, Chilón) 143

El Ajaw Tzeltal Juan López, el Pastor (Manuel Hernández, Swijlibjá, Chilón) 145

10. María Roselia Jiménez (Tojolabal) 148

Jas lo'il ja statawelo, jtatawelotikoni 150

A Tale from Our Grandfathers and

Great-Great-Grandfathers $\quad 151$

Lo que contaron nuestros abuelos y tatarabuelos 152 
11. Javier Castellanos Martínez (Sierra Zapotec) 154

Wila che be ze lhao 156

Songs of Bezelhao 162

Cantares de los vientos primerizos $\quad 167$

12. Joel Torres Sánchez (Purepecha) 174

Ji no xukuamiska, iji xurhijkirhiska!

(Mindakata) 176

I'm Not a Witch, I'm a Healer! (Selection) 179

No soy hechicera, ¡soy curandera! (Selección) 182

13. Gabriel Pacheco (Huichol) 186

Tatei Yurienaka 188

Our Mother Yurienaka 191

Nuestra Madre Yurienaka 194

14. Librado Silva Galeana (Nahuatl) 198

In temazcalli 200

The Temascal 202

El temascal $\quad 203$

15. Román Güemes Jiménez (Nahuatl) 206

Chikomexochitl: Ne konetsij tlen tiopamitl kikuajki 208

Chikomexóchitl: The Child the Church Devoured 216

Chikomexóchitl: El niño devorado por el templo $\quad 223$
Appendices/Apéndices $\quad 231$

Appendix A. The Jmeno'ob, Traditional Mayan Priests 231

Apéndice A. Los Jmeno'ob, sacerdotes mayas tradicionales 231

Appendix B. Cháak, the Mayan God of Rain 233 Apéndice B. Cháak, Dios maya de la lluvia 233

Appendix C. The Mayan Alux 235

Apéndice C. El Alux maya 235

Appendix D. The Mayan P'uus 237

Apéndice D. El P’uus maya 237

Appendix E. The Owners, Lords, or Guardians of the Earth and Water 239

Apéndice E. Los Dueños, Señores o Guardianes de la tierra y el agua 239

Appendix F. The Xut and the K'ox of Chiapas 241 Apéndice F. El Xut y el K’ox de Chiapas 241

Appendix G. The Nahuales or Tonas 243

Apéndice G. Los Nahuales o Tonas 243

Appendix H. The Huicholes and the Celestial Deer 245

Apéndice H. Los Huicholes y el Venado Celeste 245

English Glossary 247

Glosario español 253 